DOI: https://doi.org/10.32839/2304-5809/2021-5-93-8

УДК 7.038.541(477)"19"

Лісова Н.Л. ${ }^{1}$

Національна академія образотворчого мистецтва і архітектури

\title{
ФІЛОСОФІЯ ДОВКІЛЛЯ У ТВОРЧОСТІ СЕРГІЯ ЯКУНІНА
}

\begin{abstract}
Анотація. В Україні поки що відсутні фундаментальні мистецтвознавчі дослідження в напрямку лендарт, а поодинокі статті в періодичних виданнях не розкривають засади формування власне українського мистецтва довкілля, його особливості та відмінності від закордонного. Творчість Сергія Якуніна, який багато років е знаковим представником українського ленд-арту, допоки теж не висвітлено в друкованих працях. Дослідження творчості С. Якуніна, який один з перших звернувся до властивостей природних матеріалів, є важливим компонентом розвитку самобутнього вітчизняного ленд-арту. В статті розглянуто особливості творчого становлення С. Якуніна, досліджено фестивальну діяльність художника, проаналізовано знакові роботи та самостійні проекти. Проведено огляд літератури стосовно обраної теми та проаналізовано документації із особистих архівів художників.
\end{abstract}

Ключові слова: Сергій Якунін, ленд-арт, українське сучасне мистецтво, мистецтво довкілля.

Lisova Nataliia

National Academy of Fine Art and Architecture

\section{PHILOSOPHY OF THE ENVIRONMENT IN THE CREAVITY OF SERGEY YAKUNIN}

Summary. In Ukraine, there are no fundamental art studies in the field of land art, and single articles in periodicals do not reveal the principles of formation of the actual Ukrainian art of the environment, its features and differences from abroad. The creativity of Sergey Yakunin, who has been an iconic representative of Ukrainian land art for many years, has not yet been covered in print. The study of the work of S. Yakunin, who was one of the first to turn to the properties of natural materials, is an important component of the development of original domestic land art. The article considers the peculiarities of S. Yakunin 's creative formation in the system of Ukrainian contemporary art, researches the artist' s festival activity, analyzes significant works and independent projects. S. Yakunin started working in this direction long before the emergence of land art events in Ukraine, and continues his creative search both at festivals and abroad. Today the artist is an honorary participant of domestic land art festivals and symposia. Examining the formation of Sergei Yakunin's creative method, it was found that the artist's focus on working with space was laid down from a young age. Working as a sculptor with volume, space and chiaroscuro, the artist tried to go beyond the academic approach to sculpture and find the form that best expressed his ideas in space. The desire to reflect natural phenomena in art, contributed to the use of «living materials» instead of marble, plaster and bronze. It was a conscious transition from sculptural monumentality to a sense of eternity in the moment. Having analyzed the principles of Sergey Yakunin's artistic worldview, we can confidently say that the artist's creavity is distinguished by a philosophical approach and a special perception of the properties of natural materials. The article reviews the literature on the selected topic and analyzes the documentation from the personal archives of artists. The topic of the article is connected with scientific and practical tasks in the context of research of the role of S. Yakunin 's creativity in the Ukrainian art of the end of the XX - the beginning of the XXI century.

Keywords: Sergey Yakunin, land art, Ukrainian contemporary art, art of environment.

$\Pi^{2}$ остановка проблеми. Фундаментальні мистецтвознавчі дослідження напрямку ленд-арт поки що відсутні в Україні, а поодинокі статті в періодичних виданнях не розкривають засади формування власне українського мистецтва довкілля, його особливості та відмінності від закордонного. Творчість Сергія Якуніна, який багато років є знаковим представником українського ленд-арту, допоки теж не висвітлено в друкованих працях. С. Якунін не позищіонуе себе як художника ленд-арту, радше медіумом між середовищем та глядачем. Дослідження творчості С. Якуніна, який один 3 перших звернувся до властивостей природних матеріалів, стане важливим компонентом розвитку самобутнього вітчизняного ленд-арту.

Зв'язок авторського доробку з важливими науковими та практичними завданнями. Тема статті пов'язана з науковими та практичними завданнями в контексті дослідження ролі творчості С. Якуніна в українському мистецтві кінця XX - початку XXI сторіччя.
Аналіз дослідження. Попри те, що історія ленд-арту в Україні налічуе понад сорок років, досліджень, присвячених безпосередньо творчості С. Якуніна, як знакового художника мистецтва довкілля, так і загалом українському лендарту, надзвичайно мало. Існуючі джерела дають загальну характеристику творчого становлення ленд-арту в Україні, окреслюючи національну стилістику на прикладі окремих робіт.

Важливим для розуміння середовища українського ленд-арту стала монографія за редакцією П. Бевзи та Г. Гідори «Мистецтво довкілля: Україна 1989-2010». У книзі опубліковані тексти і мистецтвознавчі статті, написані Г. Вишеславським, Н. Кохан, Г. Гідорою, Г. Сидоренко, А. Блудовим, В. Бахтовим та іншими, протягом 1994-2010 років. Художниця Г. Сидоренко описує контекстуальну складову проектів, реалізованих сумісно з С. Якуніним та наводить основні художні підходи їх втілення. В альбомі зібрано світлини найбільш вагомих творчих робіт 3 
1989-2010 рік. Зокрема, представлено фротографiї робіт С. Якуніна.

Ірунтовною працею, в якій розглядається еволюція вітчизняного мистецтва середовища, $€$ стаття мистецтвознавця Г. Вишеславського «Українському ленд-арту 36 років!» у періодичному виданні «Галерея», № 34, 2008 року. Автор розглядає інституалізацію ленд-арту та згадує найперші практики, як синтез енвайронменту, перформансу і гепенінгу. Важливо, що в статті наведено приклади творчих проектів С. Якуніна та зазначено про участь С. Якуніна сумісно з Г. Сидоренко у пленері «Снов» 1992 року.

Куратор та організатор міжнародного зимового фестивалю ленд-арту «Мірогенез» художник О. Никитюк проводить екскурс у формотворення фестивалю «Міфорогенез» в каталогах «Міфогенез» за 2007, 2013, 2016 роки. Серед плеяди художників куратор згадує С. Якуніна та його роботи «Зондаж» (2013) і «Площина зі змінним кутом відображення» (2013).

Мистецтвознавиця Н. Кохан спробувала окреслити періодизацію та особливості вітчизняного ленд-арту в дисертації «Ленд-арт у контексті сучасного ландшафртного дизайну», 2019 р. Між іншим дослідниця наводить приклади робіт українських художників, серед яких зазначено проекти С. Якуніна, реалізовані під час його участі в міжнародному симпозіумі ленд-арту «Простір покордоння», що в Могриці Сумської області.

Потужним джерелом в дослідженні творчості C. Якуніна став англомовний електронний каталог творчих робіт "Sergei Yakunin. Sculpture and Site-specific Art». В збірку увійшли роботи художника за період з 1973 року по 2016 рік. Ілюстративний ряд каталогу супроводжують короткі замітки львівських дослідників Г. Хорунжи та Б. Шумиловича, які намагаються окреслити головні ідеї формотворення С. Якуніна.

Головним інформаційним джерелом в дослідженні творчості С. Якуніна стали архівні матеріали, серед яких: фрото-документація 3 особистого архіву С. Якуніна, фрото-документація 3 особистого архіву Н. Лісової, особистий архів Н. Лісової записів розмов з С. Якуніним.

Виділення невирішених раніше частин загальної проблеми. Проаналізувавши наведені джерела, доходимо висновку, що в них не достатнього глибоко висвітлена тема мистецтва довкілля. Зазначені інституції дослідженні поверхово і не є вичерпними для визначення специфріки вітчизняного ленд-арту. Таким чином, на сьогодні в мистецтвознавстві відсутні грунтовні дослідження, присвячені історичному розвиткові українського ленд-арту.

Мета дослідження - проаналізувати творчість Сергія Якуніна в контексті українського ленд-арту; провести огляд літератури стосовно обраної теми; проаналізувати документації із особистих архівів художників; розкрити особливості творчості Сергія Якуніна в контексті українського ленд-арту; дослідити становлення творчого методу С. Якуніна; проаналізувати засади художнього світогляду С. Якуніна.

Виклад основного матеріалу. Сергій Якунін - український художник, скульптор, працює в галузі фротографої, відео арту, скульптури, інсталяції, ленд-арту, сайт-специфік арт, учас- ник регіональних та зарубіжних проектів, член Галицької Мистецької Асоціації. Від самого народження (20 жовтня 1954) художник мешкає та працюе у Львові. Творчість митця вирізняється фрілософрським підходом та особливим сприйняттям властивостей природних матеріалів.

Спрямування С. Якуніна на роботу саме 3 простором було закладено ще в юності. Дитячі захоплення геометрією, кресленням, фрізикою, хімією, властивостями матеріалів від висікання іскри до експериментів в кінематиці, мали відображення у творчому пошуку художника в майбутньому. В родині Якуніних завжди панував культ мистецтва. Перебуваючи з малку в творчій атмосфрері, художник сприймав мистецтво як норму. Коли С. Якунін вирішив вступати до Львівського державного інституту декоративного та прикладного мистецтва (нині Львівська національна академія мистецтв), саме ненав'язливі поради батька художника, Івана Якуніна (викладача скульптори у вище згаданому навчальному закладі), сформували у сина профресійне розуміння простору, форми та об’ему на все життя. В процесі навчання художник отримав досвід роботи 3 різними матеріалами: в кераміці, склі (вітражі), металі (карбування), дереві; вивчав нарисну геометрію, проектування інтер'єрів, живопис i кольорознавство, шрифрти, основи композиції. Невпинні дослідження форми в майстерні батька під час навчання в інституті сприяли пошуку нових рішень у створені звиклих образів.

З 1976 року С. Якунін приймає участь в національних та міжнародних виставках і симпозіумах. Разом з батьком ліпили і вождів, і пам'ятні знаки, рельєери та дитячі майданчики. Працюючи як скульптор з об'ємом, простором та світлотінню, художник намагався вийти за рамки академічного підходу в скульптурі і віднайти ту форму, яка найкраще змогла б виразити його ідеї в просторі.

По закінченню інституту восени 1977 рощі С. Якунін вступає на строкову службу у Львові до весни 1979 року. Навіть під час служби йому довелось проектувати та офрормляти музей ВПС ПрикВО (військово-повітряних сил прикарпатського військового округу) у Львові, створювати експозицію музею льотчика П.М. Нестерова (1887-1914) у Жовкві.

Тяжіння до формотворення, експерименти 3 площиною у середовищі були підкріплені перебуванням С. Якуніна на початку 1980-х років у Москві. Саме там художник знайомиться 3 практикою місцевих концептуалістів: Едуардом Гороховським, Іллєю Кабаковим, Ігорем Макаревичем, Борисом Орловим, Дмитром Пріговим [12]. Надалі творчість Якуніна тяжіє до концептуалізму у взаємодії з простором через об’єкт та його форому.

Знаковою для художника стала зустріч 3 Франциско Інфанте. Російський художник, один з небагатьох в Москві, хто активно реалізував проекти, реалізація яких була безпосередньо пов'язана із застосуванням артефракту в навколишньому середовищі. Відповідно, творчий підхід Ф. Інфранте не тільки надихнув, а й пасував власним творчим пошукам С. Якуніна, та надав впевненості на новому етапі творчого шляху.

У 1987 році С. Якунін приймає участь у груповому проекті «Запрошення до дискусії» в Музеї 
фоотографії у Львові. (нині костелі Марії Сніжної). Організаторами проекту Володимир Арофікін та Юрій Соколов. Виставка стала знаковою у творчості художника. Подія привернула увагу альтернативних митців того часу, що спряло комунікації і знайомству художника з новими течіями мистецтва та презентації власних напрацювань досвідченій публіці.

У 1990 році С. Якунін вступае в Спілку художників України, а у 1989, 1991, 1992 роках бере активну участь у творчих пленерах в Седневі. Свого часу кураторами пленерів були: Тіберій Сільваші, Олександр Соловйов, Юлій Синькевич. Для художника пленери стали гарною можливістю попрацювати в різних художніх техніках графіки, живопису, скульптури.

Перші досліди художника із середовищем відбулися на початку 1990-х років. В цей період в Україні з'являються практики ленд-арту, як нова форма творчого пошуку та реалізації. Саме у 1992 році, на пленері у Седніві, С. Якунін разом з іншими учасниками почав взаємодіяти з природним середовищем, створювати об'єкти із зістарених побутових та господарських предметів: вози, човни, відра, рушники. Із природніх матеріалів було використано лід, лозу, повалені дерева. Самодостатні творчі роботи були наближені до інсталяцій в довкіллі. Власне, це були перші спроби сформулювати ідею роботи з природними матеріалами в поєднанні із звуком, світлом, проекцією та віднайти способи привнесення результатів у виставковий простір. Першою роботою у новому напрямку став проект «3/3» 1994 року в Київському планетарії в галереї «Світ-Л» у 1994 році, спільно з Ганною Сидоренко та Глібом Вишеславським (іл. 1). Також, на початку 1990-х років С. Якунін звертається до теми «кокона». Питання з глибокого дитинства художника, на кшталт: «Що змушуе одну субстанцію перетворитися на іншу? Як з'являеться кокон? Чому він перетворюеться на метелика?», проявляються у творчих практиках художникка як метафора: «..звідкии приповзли, і куди полетимо... ми можемо лише припускати...» [11]. Тобто, під розумінням «кокона» розглядається символічна форма нового мистецького продукту як такого, що існуе поза авторським втручанням, але "вивільнення метелика" відбуваеться за допомогою фінального творчого означення.

Твори С. Якуніна народжуються з певних ситуацій, які пропонуе оточуюче середовище. Елементи природньої стихії скеровують художника на дослідження миттевостей, що можна проявити через танення льоду, зникнення створеної з піску форми чи стікання води. Саме ці роботи не були дослідженням природи, вони радше намагалися осягнути такі характеристики вічності, як постійне становлення і розпадання. У такому контексті ідеальним для нього e буддистська практика написання текстів за допомогою води на поверхні каміння у спекотний день. Ця практика виявляе щось, що швидко зникає, - все перебуває у двох станах, постійного становлення та постійного зникання. Саме тому, С. Якунін звертаеться ще до однієї метафори - маятника з льоду (1995р.), що проявляе ритм та час через змінність власної форми (іл. 2).

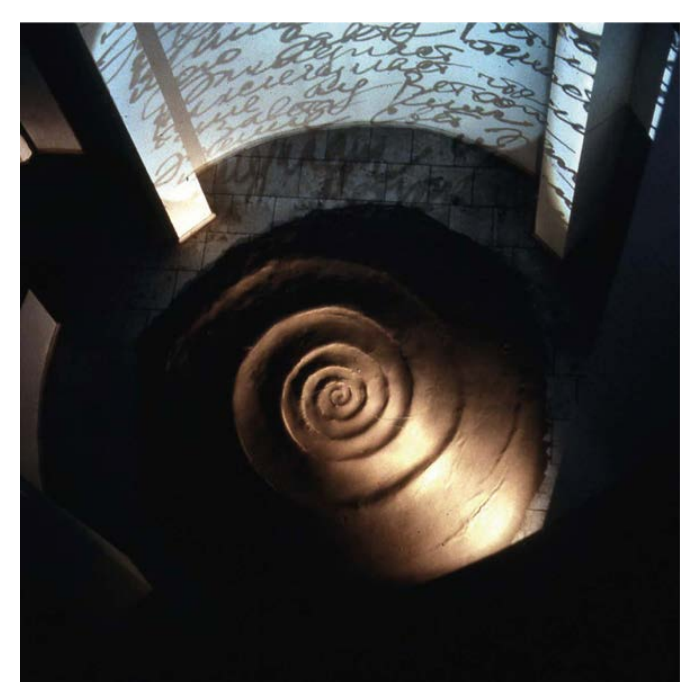

Іл. 1. Сергій Якунін, Ганна Сидоренко, Гліб Вишеславський. 3/3. 1994. Пісок, відео, слайд проекція, змішаний звук. Галерея "Світ-Л", Київський планетарій, Київ, Україна (Приватний архів Лісової Н.)

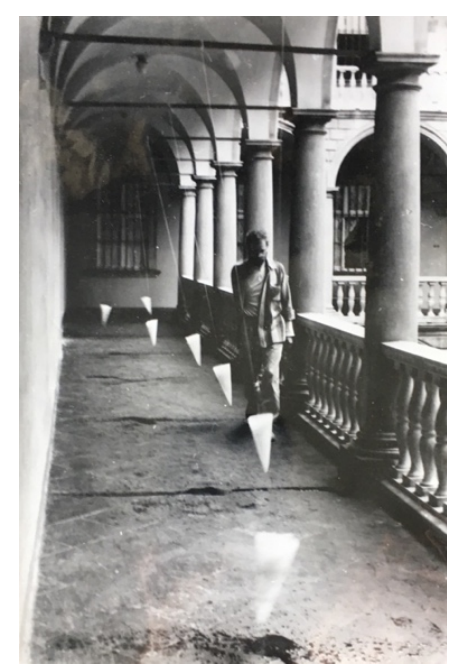

Іл. 2. Сергій Якунін. Лабораторні роботи - 03. 1995. Лід, мотузка. Історичний музей, Львів. Україна (Приватний архів Лісової Н.)

Наприкінці 1990-х роках С. Якунін працюе із ритмами природи (сезоними явищами, фізичними станами, біологічними процесами, періодичними коливаннями рівня моря), навколишній простір стае «полотном». Сергій Якунін формуе «зміщені кути» у природньому ландшафтті, будуе геометричні фрігури в просторі (трикутники та лінії), конструюе кокони (проекти «Кокон-1», «Кокон») (іл. 3, іл. 4). Важливо, що найпростіші геометричні фігури, як квадрат, трикутник та коло, i їх елементи пов'язують явища та поняття, розкривають їх зміст і метафізичний взаємозв'язок між ними.

На межі 1990-x - 2000-х років С. Якунін активно приймає участь у ленд-арт симпозіумах та фестивалях: «Wo ist Kunst? Laboratory-99» (Фраунфельд, Швейцарія, 1999), “Poetry: Installation and performance» (Нью-Йорк, США 1999), «Periferic-3» (Ясси, Румунія, 2003), «Donumenta» (Регенсбург, Німеччина), «Простір Покордоння» (Могриця, Сумська обл.), «Міфрогенез» (Вінниця), «Хортиця» (Запоріжжя), «Весняний вітер» (Київ). 

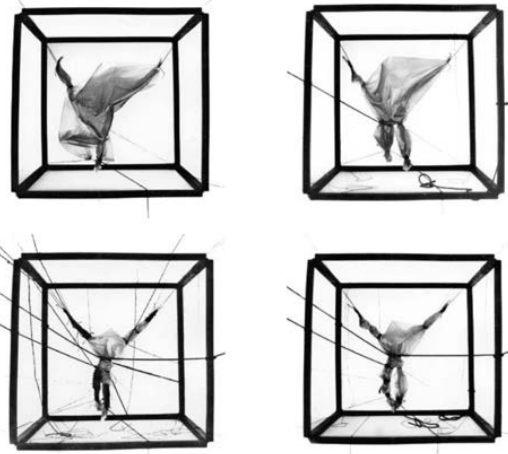

Іл. 3. Сергій Якунін. Какон-1. 1983.

Тканина, мотузка, метал. 70х70х70. (Приватний архів Лісової Н.)

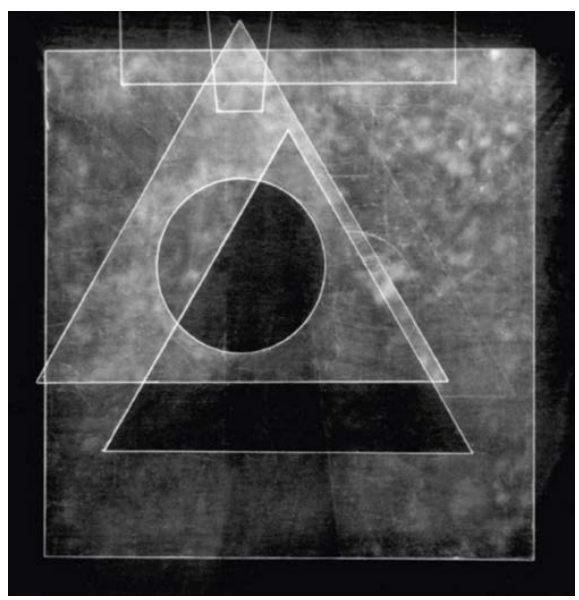

Іл. 4. Сергій Якунін. Кокон. 1991. Плексиглас. $80 \times 80 \times 120$. (Приватний архів Лісової Н.)

Особистий досвід С. Якуніна сприяв формуванню його власної, відмінної від інших, візуальної мови. Перебуваючи в пошуку засобів для втілення ідей, автор відкриває у звичних образах нові форми та поєднання, розкриваючи їх контекст. Для С. Якуніна важливо виявити ідею у просторі одним жестом (лінія, крапка, дуга), не порушуючи рівноваги. Використовуючи природні матеріали (пісок, вода, камінь, крига, дерево), митець надає вагомого значення саме ї властивостям - сипучості, текучості, звуку, блиску, рефлексу. Мистецтво довкілля стае провідним у дослідженні простору й часу. В своїх практиках С. Якунін розкривае тему становлення та розпаду матерії в природі. 3 дитинства, спостерігаючи за природними явищами, автор замислюеться над вічними процесами в їх швидкоплинності. Бажання відобразити в мистецтві схід і захід сонця, падіння крапель дощу, динаміку пейзажу, сприяло до застосування «живих матеріалів» замість мармуру, гіпсу та бронзи. Це був свідомий перехід від скульптурної монументальності до відчуття вічності у миттевості - «проміжок між двома краплями до моменту падіння» [Приватний архів Лісової Н.].

С. Якунін не позиціонуе себе як ленд-артиста, радше як медіума між середовищем та глядачем. Митець розробляе концепції, використовуючи певні форми залежно від ідеї, акцентуючи увагу глядача на певному моменті. Наприклад, розмивання піщаної лінії на березі моря «В очікуванні хвилі» (2014) (іл. 5), коливання крижаного трикутника на поверхні зимового озера «Площина зі змінним кутом відображення» (2013) (іл. 6), сповільнення руху кам'яного маятника «Стільниковий об’єкт» (1997) (іл. 7), заповнення піском скляних площин «Наповнення» (1994) (іл. 8) та ін. Свої творчі роботи митець називає артефрактами, тобто, результатами взаємодії художника i природи.

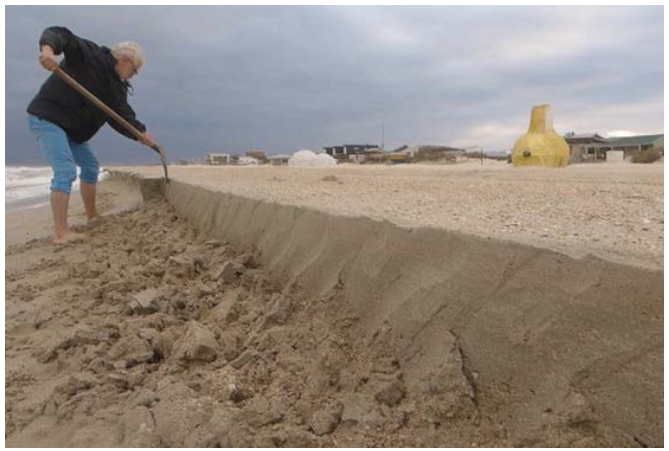

Іл. 5. Сергій Якунін. В очікуванні хвилі. 2014. Пісок, вода. Мистецька резиденція «BIRUCHIY", Бердянська коса, Запорізька область, Україна. (Приватний архів Лісової Н.)

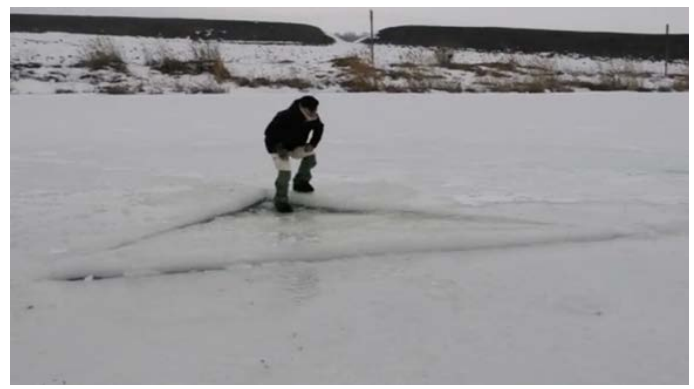

Іл. 6. Сергій Якунін. Площина зі змінним кутом відображення. 2013. Лід.

Фестиваль зимового ленд-арту «Міфогенез", Скіфські Вали, Вінницька область, Україна. (Приватний архів Лісової Н.)

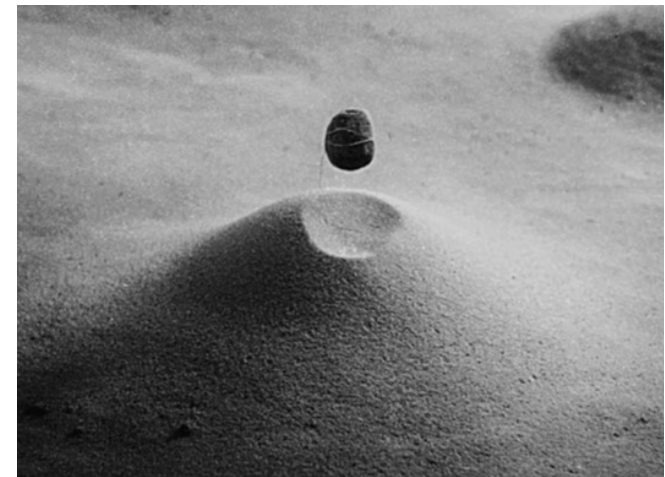

Іл. 7. Сергій Якунін. Стільниковий об'єкт. 1997. Пісок, маятник, світло, звук (Юрій Яремчук). Галерея «Д. А.», Львів, Україна. (Приватний архів Лісової Н.)

Висновки. Отже, в даній статті було розкрито особливості творчості Сергія Якуніна в контексті українського ленд-арту. С. Якунін почав працювати в даному напрямку ще задовго до виникнення ленд-арт заходів в Україні, і продовжує творчий пошук як на фестивалях, так і за їх 


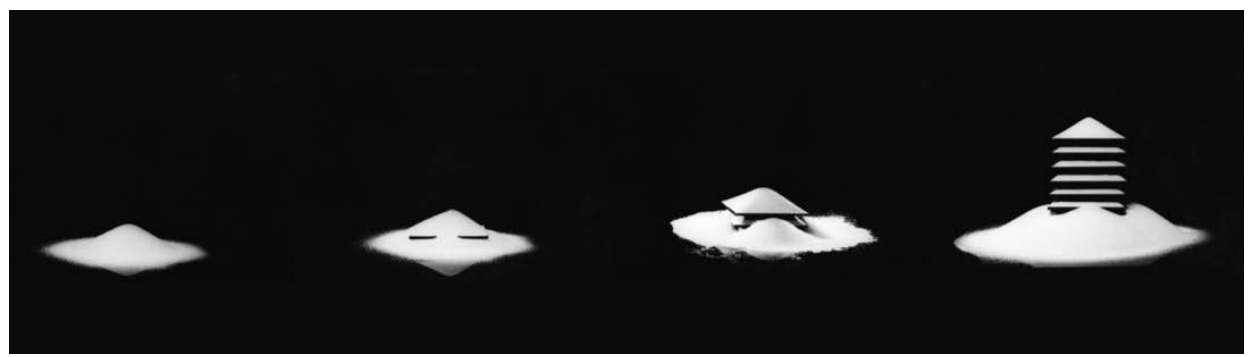

Іл. 8. Сергій Якунін. Наповнення. 1994. Пісок, скло. Львів, Україна. (Приватний архів Лісової Н.)

межами. Сьогодні художник почесний учасник вітчизняних ленд-арт фестивалів та симпозіумів. Дослідивши становлення творчого методу Сергія Якуніна було виявлено, що спрямування художника на роботу саме з простором було закладено ще 3 юнацтва. Працюючи як скульптор з об'ємом, простором та світлотінню, художник намагався вийти за рамки академічного підходу в скульптурі і віднайти ту форму, яка найкраще змогла б виразити його ідеї в просторі. Бажання відобразити в мистецтві природні явища, спри- яло застосуванню «живих матеріалів» замість мармуру, гіпсу та бронзи. Це був свідомий перехід від скульптурної монументальності до відчуття вічності у миттевості. Таким чином, фрілософрське підгрунття стає для митця визначальним в його подальших пошуках. Проаналізувавши засади художнього світогляду Сергія Якуніна, можемо впевнено сказати, що творчість митця вирізняється фрілософським підходом та особливим сприйняттям семантичних змістів природних матеріалів.

\section{Список літератури:}

1. Вишеславський Г. Ленд-арт у творчості українських митців. Сучасне листеитво. 2017. № 13. С. 59-72.

2. Вишеславський Г. Українському ленд-арту 36 років. Галерея. 2008. № 3/4 (35/36). С. 9-15.

3. Кохан Н.М. Ленд-арт у контексті сучасного ландшафртного дизайну : дис. канд. мистецтвознавства : 17.00 .07$. Харків, 2019. 171 с.

4. Лісова Н. Український ленд-арт, в контексті розвитку сучасної української культури / Сьомі Платонівські читання. Тези доповідей Міжнародної наукової конференції. Київ : Видавництво Людмила, 2020. С. 109-110.

5. Лісова Н. Формування спещиріки українського ленд-арту / Мистецька культура: історія, теорія, методологія : тези доповідей VIII Міжнар. наук. конф. (Львів, 20 листопада 2020 р.) / НАН України, ЛННБ України iм. В. Стефаника, Ін-т досліджень бібліотечних мистецьких ресурсів; ред-упоряд.: Л. Купчинська, О. Осадця; відп. Ред. Л. Сніцарук. Львів, 2020. С. 133-134.

6. Лісова Н. Формування специфіки українського ленд-арту / Актуальні питання культурології: Альманах наукового товариства «Афріна» кафедри культурології та музеєзнавства. Вип. 20 / За ред. проф. В. Г. Виткалова. Рівне : РДГУ, 2020. С. 105-112.

7. Лісова Н. Ленд-арт як спосіб формотворення в роботах Сергія Якуніна / Восьмі Палатонівські читання. Тези доповідей Міжнародної наукової конференції. Київ : СПД Чалчинська Н.В., 2021. С. 98-99.

8. Мистецтво довкілля: Україна 1989-2010: Альбом / упор. П. Бевза, Г. Гідора. Київ : Софрія-А, 2010.200 с.

9. Никитюк О. Міфогенез. Міфогенез. Вінниця, 2016. 100 с.

10. Приватний архів Лісової Н.

11. Sergei Yakunin. Sculpture and Site-specific Art. Kyiv: Stedley Art Foundation, 2021. 168 p.

12. Якунін Сергій. URL: https://mitec.ua/category/artists/yakunin-sergey/

\section{References:}

1. Vysheslavsjkyy Gh. (2017) Lend-art u tvorchosti ukransjkykh mytciv». Suchasne mystectvo, no. 13, pp. 59-72.

2. Vysheslavsjkyy Gh. (2008) Ukraïnsjkomu lend-artu 36 rokiv. Ghalereja, no. 3/4 (35/36), pp. 9-15.

3. Kokhan N.M. (2019) Lend-art u konteksti suchasnogho landshaftnogho dyzaynu: dys. kand. mystectvoznavstva: 17.00.07. Kharkiv, $171 \mathrm{p}$.

4. Lisova N. (2020) Ukrainsjkyy lend-art, v konteksti rozvytku suchasnoï ukraïnsjkoï kuljtury / Sjomi Platonivsjki chytannja. Tezy dopovidei Mizhnarodni naukovoi konferenciji. Kyiv: Vydavnyctvo Ljudmyla, pp. 109-110.

5. Lisova N. (2020) Formuvannja specyfiky ukrajinsjkogho lend-artu / Mystecjka kuljtura: istorija, teorija, metodologhija: tezy dopovidej VIII Mizhnar. nauk. konf. (Ljviv, 20 lystopada 2020 r.) / NAN Ukrajiny, LNNB Ukrajiny im. V. Stefanyka, In-t doslidzhenj bibliotechnykh mystecjkykh resursiv; red-uporjad.: L, Kupchynsjka, O. Osadcja; vidp. Red. L. Snicaruk. Ljviv, pp. 133-134.

6. Lisova N. (2020) Formuvannja specyfiky ukrajinsjkogho lend-artu / Aktualjni pytannja kuljturologhiji: Aljmanakh naukovogho tovarystva "Afina» kafedry kuljturologhiï ta muzejeznavstva. Vol. 20 / Za red. prof. V. Gh. Vytkalova. Rivne: RDGhU, pp. 105-112.

7. Lisova N. (2021) Lend-art jak sposib formotvorennja v robotakh Serghija Jakunina / Vosjmi Palatonivsjki chytannja. Tezy dopovidey Mizhnarodnoi naukovoi konferenciji. Kyiv: SPD Chalchynsjka N.V., pp. 98-99.

8. Mystectvo dovkillja: Ukraïna 1989-2010: Aljbom (2010) / upor. P. Bevza, Gh. Ghidora. Kyïv: Sofija-A, 200 p.

9. Nykytjuk O. (2016) Mifoghenez. Mifoghenez. Vinnycja, 100 p.

10. Pryvatnyj arkhiv Lisovoji N.

11. Sergei Yakunin (2021) Sculpture and Site-specific Art. Kyiv: Stedley Art Foundation, 168 p.

12. Jakunin Serghij. URL: https://mitec.ua/category/artists/yakunin-sergey/ 